\title{
Native Tears: Conflict on the Colonial Frontier and $R$ v Kilmeister (No 2)
}

\author{
Haydn Marsh
}

\section{Abstract}

It is undisputed that the Myall Creek massacre of 1838, which saw the brutal murder of 28 Aboriginal Australians in the harsh conditions of colonial NSW, continues to be one of the darkest days in Australian history. As such it is appropriate in the light of modern considerations of reconciliation that the causes behind the events which took place at Myall Creek, and the consequences of the litigation which followed, be critically examined from both a legal and historical perspective. This essay seeks to explore why the litigation surrounding the Myall Creek massacre caused such disruption in the context of the frontier conditions of colonial NSW. It also seeks to examine the appropriateness of the actions of the colonial authorities, and the extent to which the atrocities which occurred following the completion of the trial of $R v$ Kilmeister (No 2) can be attributed to the colonial Government. In making this examination this essay will consider both legal and historical sources, and demonstrate that the conflict between the law recognising Aboriginal Australians as subjects of the crown and therefore afforded protections of the state, and the sentiments of frontier colonists, caused an inconsistent application of the law, and ultimately resulted in further lawlessness on the colonial frontier with horrific consequences for Aboriginal Australians.

\section{Introduction}

Through an examination of the legal and historical environment surrounding the Myall Creek massacre this essay will argue that there was a conflict present in colonial New South Wales (NSW) between the enforced formal law which enshrined the recognition of Aboriginal Australians as subjects of the Crown, and the real conditions of the colonial frontier where considerations of law were subjugated to considerations of survival and emerging behavioural norms. This conflict, as evident through the litigation surrounding the Myall Creek massacre; the range of public opinion as expressed by the colonial newspapers; the massacre at Waterloo Creek; and the discretionary actions of Governor 
Gipps, resulted in an inconsistent application of the law surrounding Aboriginal Australians in colonial NSW. Through the eyes of frontier colonists it was this inconsistent enforcement and application of the law that led to feelings of abandonment, leaving them to take the law into their own hands resulting in the indiscriminate murder of numerous Aboriginal Australians. This essay will seek to explore the role that the inconsistent application of law on the frontier played in the injustices subsequently committed against Aboriginal Australians and the extent to which the colonial NSW Government's actions can be attributed to these injustices.

\section{Subjects of the Crown vs Sport of the Colonists}

In 1787 then NSW Governor Arthur Phillip received instructions as to how relations with the native population of Australia were to be conducted. The Governor was required to ensure that the colony " conciliate" the affections of the Aborigines and "live in amity and kindness with them".' ${ }^{\prime}$ Further the Governor was required to "punish those subjects who "wantonly" destroy the Aborigines. $^{2}$

Fifty years further on, this aspiration to protect the native populations of NSW was still being pursued by the colonial authorities. In the important and much cited 1836 case of R. $v$ Jack Congo Murrell ${ }^{3}$ the NSW Supreme Court had to decide whether the native 'Murrell', who had killed a fellow Aboriginal man, was to be subject to British law. ${ }^{4}$ Ultimately 'Murrell' was not convicted on the basis of a lack of evidence, however this did not preclude the court from finding that Aboriginal Australians were indeed subject to, and afforded the protection of, British law. ${ }^{5}$ This finding was significant as it meant not only that Aboriginal Australians could be found liable for killing a fellow Aborigine, but as they were subjects of British law, they could also be found guilty of crimes against colonists, and importantly colonists would be liable for crimes committed against them. ${ }^{6}$ It was this last listed effect of the decision in Murrell which would be the subject of controversy in the context of the litigation surrounding the Myall Creek massacre.

Although the decision in Murrell could be said to have clearly established the law in the colony with respect to the legal status of Aboriginal Australians,

\footnotetext{
1 Alex Castles, An Australian Legal History (Law Book Company, 1982) 520, quoting 'Instructions to Arthur Phillip Esq.' 1(1) Historical Records of Australia - Governors Despatches, 25 April 1787.

2 Ibid.

3 R v Jack Congo Murrell (1836) 1 Legge 72.

4 Bruce Kercher, An Unruly Child: A History of Law in Australia (Allen \& Unwin, 1995) 9.

5 Ibid, 10.

6 Ibid, 9.
} 
there still remained a considerable divide between the practical enforcement of this law, particularly concerning the protection of natives against colonists. Travelling colonial settler W.H. Breton clearly described the attitude of frontier colonists towards 'blacks' in a section of his book entitled 'Frontier Retaliation':

In case of any serious affray with the blacks, it really would appear to be the most judicious plan, to make upon them at once, a strong impression; for if only one or two be killed, the sole effect is to instigate them to revenge their companions, whereby a series of murders on both sides is the consequence! ...they should not be permitted to harrass [sic] the settlers with impunity: we have taken possession of their country, and are determined to keep it; if, therefore, they destroy the settlers or their property they must expect that the law of retaliation will be put in force, and that reprisals will be committed upon themselves. ...they [Aborigines] have been wantonly butchered; and some of the Christian whites consider it a past time to go out and shoot them. ${ }^{7}$

This extract shows clearly the attitude of frontier settlers immediately preceding the Murrell decision. Rather than treating the indigenous population as equals under British law, Breton recalls how Aboriginal Australians were 'wantonly' shot for sport, and how even himself as an educated man considered it appropriate for the settlers to be enforcing a 'law of retaliation'. Whilst this account predates the Murrell decision by up to 6 years (Breton compiled his account over 4 years from $1830-4)^{8}$ it is very unlikely that any significant change manifested in the settlers behaviour or attitude towards the Aborigines during this interlude. One could even argue that the events at Myall Creek themselves demonstrate the accuracy of Breton's account of the frontier settler's attitudes towards the native populace.

These examinations of the Murrell decision, and Breton's travel journal demonstrate the significant conflict present in colonial NSW between the law as determined by the authorities, and the behavioural norms of frontier settlers who felt genuinely justified in enforcing a 'law of retaliation' in lieu of adequate state protection.

\section{Conflict in $R$ v Kilmeister (No 1)}

It was from this environment of disparate conceptions of law and justice that the turmoil of the Myall Creek massacre manifested. Governor Gipps is recorded as

7 William Henry Breton, Excursions in New South Wales, Western Australia, and Van Diemen's Land (Richard Bentley, 1835) 176-7.

8 Ibid. 
having first heard of the events at Myall Creek at the end of June 1838, almost twenty days after the massacre had taken place. ${ }^{9}$ Upon hearing the news Gipps is said to have gone 'through a terrible anguish of the heart and mind'10 and after consulting with the Attorney-General John Plunkett, ordered an investigation of the events. ${ }^{11}$ After several weeks the mounted police returned with evidence, and eleven of the twelve men accused of murder. The first trial ensued soon after with all eleven men being tried specifically for the murder of an Aboriginal man called 'Daddy'. ${ }^{12}$ Despite what was considered to be conclusive and damning evidence, the accused were acquitted at first instance based seemingly upon the inability of an Aboriginal witness to give evidence. ${ }^{13}$

At the same time, while colonial authorities had been pursuing the conviction of the accused men for murder, the sentiment of colonial settlers was being strenuously raised in objection. Following Gipps order of investigation and in the lead up to the first trial the 'squatter's newspaper, the Sydney Herald' had been persistently advocating the injustice of prosecuting the accused men. ${ }^{14}$ The Herald's particular focus had been on criticising the government for their failure to protect 'whites against blacks' whilst pursuing the prosecution of the eleven accused men. ${ }^{15}$ The advocacy of the Herald continued to strengthen in the lead up to the first trial as evident in this extract from 14 September 1838 :

The government, it is evident, will not, or cannot protect the whites from the aggression of the blacks - it behoves the former, therefore to protect themselves; and this they can most effectively do in the jurybox, by determining not to convict persons on charges originating in collisions with the blacks... ${ }^{16}$

It can be seen from this extract that the Herald was actively encouraging prospective members of the jury not to convict settlers of crimes committed against Aboriginal Australians, so to ensure their own legal protection. This extract clearly demonstrates the conflict present between the law being applied by the colonial authorities and the sentiments of the settlers. However, tensions only rose as the litigation progressed.

9 Brian Harrison, The Myall Creek massacre and Its significance in the controversy over the Aborigines during Australia's early squatting period (BA thesis, University of New England, 1966) 23.

10 Manning Clarke, History of Australia (Melbourne University Press, 1973) vol 3, 144.

11 John Gipps, Every Inch a Governor (Hobson's Bay Publishing, 1996) 69-70.

$12 R$ V Kilmeister (No 1) [1838] NSWSupC 105.

13 Gipps, above $\mathrm{n} \mathrm{11,70,} \mathrm{citing} \mathrm{'Gipps} \mathrm{to} \mathrm{Glenelg'} \mathrm{1(19)} \mathrm{Historical} \mathrm{Records} \mathrm{of} \mathrm{Australia} \mathrm{-} \mathrm{Governors}$ Despatches, 20 December 1938.

14 Kercher, above n 4, 13.

15 Ibid.

16 'Continued depredations committed by the blacks', The Sydney Herald (online), 14 September 1838, 2 $<$ http://trove.nla.gov.au/ndp/del/page/1525196?zoomLevel=2>. 


\section{A Considered Review}

Following the acquittal of the eleven men, Governor Gipps and Attorney-General Plunkett immediately moved for a retrial of seven of the accused men, this time in relation to the killing of a child christened 'Charley'.${ }^{17}$ The Attorney-General and the Governor were committed to ensuring that justice was seen through, and this time they were joined by Justice William Burton who made the leading judgement in the Murrell decision, and was renowned for his strict reliance upon and fidelity to English laws. ${ }^{18}$ Burton J's conduct during the trial was consistent with his decision in Murrell and according to renowned Australian legal historian Kercher 'he left the jury in little doubt that he felt the defendants were guilty.' ${ }^{19}$ In making his final instructions to the jury before they considered their verdict, Burton J emotively redescribed the facts of the case:

This massacre was committed upon a poor defenceless [sic] tribe of blacks, dragged away from their fires at which they were seated, resting secure in the protection of one of the prisoners; unsuspecting harm, they were surrounded by a body of horsemen, twelve or thirteen in number, from whom they fled to the hut, which proved the mesh of destruction. In that hut, the prisoners, unmoved by the tears, groans, and sighs, bound them with cords, fathers, mothers, and children, indiscriminately, and carried them away to a short distance, when the scene of slaughter commenced, and stopped not, until all were extirminated [sic]. ${ }^{20}$

In this instance the jury followed the path laid out by Burton $\mathrm{J}$ and returned a verdict of guilty. ${ }^{21}$ Several days later the court returned, and Burton J with tears in his eyes in front of a crowded gallery, sentenced the seven men to death. ${ }^{22}$

\section{The Peak of Political Courage}

Following the trial there was an immense outcry of public dissatisfaction with the decision and the sentence. In the month following the trial the Crown brought a case against two Sydney publicans who had been accused of

\footnotetext{
17 Kercher, above n 4, 14.

18 See Roger Milliss, Waterloo Creek: The Australia Day Massacre of 1838, George Gipps and The British Conquest of New South Wales (University of New South Wales Press, 1994) 529-539; Clarke, above n 10, 147148; Kercher, above n 4, 87; Bruce Kercher, 'Many Laws, Many Legalities' (2003) 21 Law and History Review, 621,622 .

19 Kercher, above n 4, 14.

$20 R v$ Kilmeister (No 2) [1838] NSWSupC 110.

21 Castles, above n 1, 523.

22 Kercher, above n 4, 14; Milliss, above n 18, 545-546.
} 
publically threatening the foreman of the jury in $R v$ Kilmeister (No2). The case itself reported that the foreman 'in consequence of the verdict he had returned, had been abused and insulted' ${ }^{23}$

In addition the Herald's response was predictably severe, as they attempted to place pressure upon Governor Gipps to exercise his power of clemency to have the convicted men avoid the noose. On the 10th of December 1838 the editors of the paper published sentiment that regardless of the convicted men's innocence or guilt, their execution would be 'nothing short of legal murder' and if carried out would 'incite an actual war of extermination' against the natives.' ${ }^{24}$ As such the settlers, through the Herald, were practically threatening the Governor: that should he choose not to extend clemency, the frontier colonists would actively ensure the enforcement of their own law of retaliation.

Gipps however, in what has been described as the 'peak in his political courage 25 did not extend mercy to the convicted men, ${ }^{26}$ and on 18 December the men fell to their deaths after having admitted their guilt to a prison guard, but stating that as it had been done so many times before they did not realise they were committing a crime. ${ }^{27}$

Despite having worked so hard in pursuing the conviction of the seven men for the Myall Creek massacre, and having established an applicable precedent, the colonial government then proceeded to step away from this policy. The investigation of a considerably larger massacre at the hands of colonial mounted police during the term of interim governor Snogdon, mere months before the events at Myall Creek, had at first been pursued by Governor Gipps. ${ }^{28}$ Upon Myall Creek surfacing, the investigations of the Waterloo Creek massacre were put on hold, to be continued upon completion of the litigation. ${ }^{29}$ When this time came Governor Gipps did at first pursue the issue, ${ }^{30}$ however within 24 months the potential prosecution of the men responsible for the murder of up to 300 Indigenous Australians had been left to fade into obscurity. ${ }^{31}$ In a Governors dispatch to Baron Glenelg, Gipps remarked on an appropriate distinction being present between the two massacres, despite there having been possibly ten

\footnotetext{
23 R. v. Douglass [1838] NSWSupC 112.

24 Milliss, above n 18, 552, quoting 'Will the executive government cause the sentence to be carried into actual execution?', The Sydney Herald (online), 10 December 1838, 2 <http://trove.nla.gov.au/ndp/del/ page $/ 1525350$ ?zoomLevel $=1>$.

25 Kercher, above n 4, 14.

26 Milliss, above $\mathrm{n} 18,555-6$.

27 Roger Therry, Reminiscences of thirty years' residence in New South Wales and Victoria (Sydney University Press, first published 1863, 1974 ed) 283.

28 Gipps, above n 11, 68-9; see also Milliss, above n 18.

29 Milliss, above n 18, 318.

30 Ibid, 599-601

31 Ibid; Kercher, above n 4, 15.
} 
times the amount of people killed. ${ }^{32}$ Gipps found that it would not be tenable to prosecute the volunteer men of the mounted police, who were at the time acting under instruction from acting Governor Snogdon and Major Nunn, despite there being no clear legal authority to legitimise their actions, and the presence of a clear precedence arising out of $R v$ Kilmeister (No 2). ${ }^{33}$

In addition to this reversal, the prosecution of the remaining four men who had been arrested for the events at Myall Creek was never ultimately brought to trial. The given reasoning behind this administrative decision was that evidence was required from an indigenous man who was present at the massacre, but due to his inability to validly give an oath he could not be brought before the court. ${ }^{34}$ On reflection this reasoning however seems incongruous with the result of $R v$ Kilmeister (No 2), where seven men were successfully convicted on what would be exactly the same evidence, even in the absence of this witness.

From these two examples it is evident that following the execution of the seven convicted men, the colonial government started bowing under the pressure of the frontier colonists in relation to enforcing the precedence established by $R v$ Kilmeister (No 2). This inconsistent application of the law regarding Aboriginal Australians would have acted to build considerable uncertainty for the colonial settlers, adding to feelings of helplessness and insecurity which were already rife on the frontier.

\section{Native Tears - The Cost of Conflict and the Role of the Colonial Government}

In the years following the conclusion of $R v$ Kilmeister (No 2) there was great unrest in the colony, particularly on the frontiers where settlers had adopted the advice of the Herald and had taken the law into their own hands, 'inciting an actual war of extermination'. ${ }^{35}$ Notable Australian historian Manning Clark in his A History of Australia lamentably comments on this period of 'payback killings' writing that:

"[the executions] only served to make the blacks so outrageous that great numbers of them fell victim in 1839 to the vindictive spirits kindled in the hearts of white men." 36

\footnotetext{
32 Kercher, above n 4, 15; Gipps, above n 11, 68-69; Milliss, above n 18.

33 Kercher, above n 4, 15; Milliss, above n 18; Castles, above n 1, 522-3.

34 Milliss, above n 18, 605-9; Kercher, above n 4, 14-5.

35 'Will the executive government cause the sentence to be carried into actual execution?', The Sydney Herald (online), 10 December 1838, 2 <http://trove.nla.gov.au/ndp/del/page/1525350?zoomLevel=1>.

36 Clark, above n 10, 149.
} 
The subsequent indiscriminate killing of Aboriginal Australians, coined by Clark as the 'payback killings' necessarily leads to a consideration of the events which took place, particularly an examination of the appropriateness of the actions of the colonial authorities, considering the ultimate consequences. This examination is particularly relevant in light of the identified conflict present in colonial NSW, and the inconsistent application of the law preceding and immediately following the conclusion of $R v$ Kilmeister (No 2).

The question as to whether the killing of countless Aboriginal Australians in colonial NSW could have been avoided through a more thorough and consistent application of the law as established in $R v$ Kilmeister ( No 2) is relevant. However it should be noted that a more thorough application of the law would have depended heavily upon there being adequate resources to undertake such an exercise. This would somewhat preclude the validity of this criticism, although it should be noted that in the two examples given above, the scarcity of resources was not cited as a relevant concern. Indeed for the prosecution of the remaining men accused of committing the Myall Creek massacre, commencing action against the men would have required the use of very limited resources considering that all the arguments and evidence had already been used to secure the conviction of the first seven men. As such it is viable to suggest that a more consistent and thorough application and enforcement of the law may have mitigated the extent of the payback killings. Although it must also be considered that a stronger approach, may in turn have provoked a stronger reaction, and therefore an argument that the authorities failed in not enforcing the law more consistently and thoroughly is limited.

A further question can be raised as to the appropriateness of the colonial authority's decision to pursue the offenders of the Myall Creek massacre with the vigour in which they did. This query is particularly relevant given the limited resources at the hands of colonial authorities, and the clear frontier sentiment present, as would have been abundantly evident through media such as the Herald. Given these restraints it may be that it would ultimately have been best for the Indigenous populace of the colony if no action had been taken. However such a decision not to pursue the case could easily have been criticised considering the morally 'depraved' ${ }^{37}$ actions of the convicted men. Also further inaction on the part of the colonial authorities in relation to the killing of Aboriginal Australians, could have been interpreted by frontier colonists as an official mandate to continue as they were. For these reasons, it is not valid to suggest that the colonial authorities erred in pursuing the conviction of seven of the men responsible for the massacre. 
Given therefore the flaws present in advocating for both inaction and increased action on the part of the colonial authorities, it would seem that their actions were in the complicated context, not altogether inappropriate. Although in light of the horrific consequences of the events surrounding the Myall Creek massacre, this author would seek to suggest that more could have been done to mitigate the outrage which affected the frontier colonists and spurred the onset of payback killings. In particular if clemency had been extended to the convicted men, and their sentence downgraded, this may have lessened the feelings of hopelessness experienced by frontier colonists, who were not being adequately protected by the government. This would also not have altered the establishment of the strong precedent set by $R v$ Kilmeister (No 2) against the indiscriminate killing of Aboriginal Australians. The position may also have been further enhanced if the voice adopted by colonial authorities had been more moderate and considered.

On 22 November 1938 The Australian published a conversation recorded between Governor Gipps and a wealthy grazier:

Settler: I have called upon your Excellency for the purpose of representing the dreadful state of the southern districts in consequence of the repeated aggressions of the aborigines.

Sir George: What do you require? The aborigines are subject to the laws of the country, which I apprehend are sufficient to protect every one, both whites and blacks.

Settler: It is impossible to apprehend the natives; and when they are apprehended they cannot be tried for their offences, inasmuch as no person can interpret their language. An armed force is the only remedy that can effectually protect our interests.

Sir George: It is a question of great difficulty. It cannot be expected that every person who wanders into the interior and herds is to be protected by an armed force. The government cannot interfere, Sir, in the way you require.

Settler: Then, your Excellency, although I for one shall regret the result, still, for our own protection, and for the protection of the lives of our servants, and flocks and herds, we must take the law into our own hands.

Sir George: Very well, Sir, you can do as you like; but you will remember that if either you or your servants commit any murders upon 
the aborigines, or if you abet them in doing so, and either you or they are tried for it and are found guilty, so sure as my name is GEORGE GIPPS, So sure shall you or they be hanged! ${ }^{38}$

It is clear from the emphasis added by the article that Governor Gipps had adopted a confrontational tone in this discussion, and appeared to be disregarding the practical impasse which the settler appeared to be in. Were the authorities to have adopted a more understanding and constructive tone on this matter to be used in examples such as the one given, it may be that the feelings of hopelessness held by the colonists would have been somewhat avoided and the payback killings somewhat mitigated.

\section{Conclusion}

From an examination of relevant case law, including $R v$ Kilmeister (No 2), and historical documents and newspapers, it is clear that there was a substantial conflict in colonial NSW between the law recognising Aboriginal Australians as subjects of the crown afforded the appropriate protections, and the sentiments of frontier colonists concerned for their welfare and property. This conflict acted to aggravate the litigation surrounding the Myall Creek massacre, and as a result pressured colonial authorities into applying the precedence established by $R$ $v$ Kilmeister (No 2) in an inconsistent manner. The conflict and inconsistency surrounding the law and its application, as well as the inability of the government to adequately protect all of its subjects living on the frontiers, led to feelings of anger and helplessness forcing the colonists to take the law into their own hands and instigating the payback killings against Aboriginal Australians.

This essay does not seek to suggest that the jury reached the wrong verdict in the case of $R v$ Kilmeister (No2), nor that the colonial authorities erred in pursuing the conviction of the men responsible for the massacre. Such a conclusion would be morally reprehensible considering the nature of the atrocities committed at Myall Creek in 1838. Indeed it has been found that the actions of the authorities in pursuing the case were not inappropriate considering the complex environment at the time. Where this essay does level criticism is towards the tone and approach adopted by the authorities, particularly Governor Gipps, over the course of the litigation. If greater consideration were given towards the possible consequences of not awarding clemency, or adopting a combative tone in a public sphere, the payback killings following the executions may have been somewhat mitigated.

38 'The Black Association' The Australian (online), 22 November 1838, $2<$ http://trove.nla.gov.au/ndp/del/ page/4298598>. 
It is in the causal cost of these shortcomings that the true significance of the events which occurred at Myall Creek are visible, for the narrative told transcends the single disciplines of law and history, and there is, at the heart of it, a tragedy of which greater consideration and contemplation is needed in the context modern Australia, reconciliation, and the law.

\section{Bibliography}

\section{Articles, Books, Reports}

Bennett, J.M., Alex C. Castles, A Source Book of Australian Legal History (Law Book Company, 1979)

Breton, William Henry, Excursions in New South Wales, Western Australia, and Van Diemen's Land (Richard Bentley, 1835)

Castles, Alex C., Annotated Bibliography of Printed Materials on Australian Law 1788-1900 (Law Book Company, 1994)

Castles, Alex, An Australian Legal History (Law Book Company, 1982)

Castles, Alex C., 'Reception and Status of English Law in Australia' (1963-66) 2 Adelaide Law Review, 1

Clark, Manning, History of Australia (Melbourne University Press, 1973) vol 3

Connors, Libby, 'Sentencing on a Colonial Frontier: Judge Therry's Decision at Moreton Bay' (2008) 12 Legal History, 81

Gipps, John, Every Inch a Governor (Hobson's Bay Publishing, 1996)

Harring, Sidney L., 'Killing Time: A History of Aboriginal Resistance in Colonial Australia' (1994) 26 The Ottawa Law Review, 385

Harris, Mark, 'Mapping Australian Postcolonial Landscapes: From Resistance to Reconciliation' (2003) 7 Law Text Culture, 91

Kercher, Bruce, 'Alex Castles on the Reception of English Law' (2003) 7 Australian Journal of Legal History, 37

Kercher, Bruce, 'Many Laws, Many Legalities' (2003) 21 Law and History Review, 621

Kercher, Bruce, 'Establishment, Freedom of Speech and the Church of England: Pew Disputes in Early Nineteenth-Century New South Wales' (2000) 6 Australian Journal of Legal History, 135 
The ANU Undergraduate Research Journal

Kercher, Bruce, 'Homer in the Australian ALPS: Attitudes to Law since 1788' (1995) 1 Australian Journal of Legal History, 1

Kercher, Bruce, An Unruly Child: A History of Law in Australia (Allen \& Unwin, 1995)

McCulloch, S.C., George Gipps (Oxford University Press, 1966)

Milliss, Roger, Waterloo Creek: The Australia Day Massacre of 1838, George Gipps and The British Conquest of New South Wales (University of New South Wales Press, 1994

Moloney, J.N., An Architect of Freedom: John Hubert Plunkett in New South Wales 1832-1869 (Australian National University Press, 1973)

Salter, Brent, 'Early interactions between indigenous people and settlers in Australia's first criminal court' (2009) 83 Australian Law Journal, 56

Therry, Roger, Reminiscences of thirty years' residence in New South Wales and Victoria (Sydney University Press, first published 1863, 1974 ed)

\section{Cases}

MacDonald v Levy [1833] NSWSupC 47

R. v. Douglass [1838] NSWSupC 112

R v Elliot [1834] NSWSupC 11

R v Jack Congo Murrell (1836) 1 Legge 72

R v Kilmeister (No 1) [1838] NSWSupC 105

R. v. Kilmeister (No.2) [1838] NSWSupC 110

\section{Legislation}

Australian Courts Act 1834 (Imp.)

Bushranging Acts 1832 (N.S.W.)

\section{Other}

'Continued depredations committed by the blacks', The Sydney Herald (online), 14 September 1838, 2 <http://trove.nla.gov.au/ndp/del/page/1525196?zoomLevel=2>

'Gipps to Glenelg' 1(19) Historical Records of Australia - Governors Despatches, 20 December 1938

'Instructions to Arthur Phillip Esq.' 1(1) Historical Records of Australia Governors Despatches, 25 April 1787 
'The Black Association' The Australian (online), 22 November 1838, $2<$ http:// trove.nla.gov.au/ndp/del/page/4298598>

'Will the executive government cause the sentence to be carried into actual execution?', The Sydney Herald (online), 10 December 1838, $2<$ http://trove. nla.gov.au/ndp/del/page/1525350?zoomLevel=1> 